\title{
Effects of organic fertilizers on the
}

vegetative, nutritional, and productive

parameters of blueberries 'Corona',

'Legacy', and 'Liberty'

Pablo Muñoz-Vega ${ }^{1}$, Hernān Paillān ${ }^{2}$, Humberto Serri ${ }^{1}$, Denise Donnay ${ }^{3}$,

Carlos Sanhueza ${ }^{3}$, Emilio Merino ${ }^{3}$, and Juan Hirzel ${ }^{4 *}$

\section{ABSTRACT}

Organic farming does not allow using certain inputs, such as $\mathrm{N}$, which differ in nutrient release rates and dynamics. To evaluate the effect of different organic fertilizers on the vegetative, nutritional, and productive parameters of blueberries (Vaccinium corymbosum L.), a pot experiment was conducted in three consecutive seasons in a sandy soil of south-central Chile using 'Corona', 'Legacy' and 'Liberty'. The following fertilizers were evaluated: compost (CM), Purely Grow (PG), Purely Lysine (PL), Fertil (F), blood meal (BM), lupine meal (LM), along with a control treatment without fertilization (C) and two conventional treatments with urea $(\mathrm{CF})$ and sodium nitrate (S). Results indicate that vegetative growth and leaf $\mathrm{N}$ concentration prior to senescence were different among cultivars in the three evaluated seasons. The highest leaf $\mathrm{N}$ concentration was recorded in 'Corona' followed by 'Legacy' and 'Liberty' while levels tended to increase in the seasons. Quick-release N sources had greater effects on these parameters but with differences among cultivars. Fruit yield and weight were higher in 'Corona' followed by 'Legacy' and 'Liberty'. Fruit yield was generally higher when using LM and F and showed no effect on fruit weight. Leaf chlorophyll content was higher in 'Corona' followed by 'Legacy' and 'Liberty', which increased when using CF, LM, BM, and PG. Finally, the organic fertilizer and blueberry cultivar that obtained the highest values for most of the evaluated parameters were LM and Corona, respectively.

Key words: Blueberry, growth and production, nitrogen, organic fertilization, Vaccinium corymbosum.

${ }^{1}$ Universidad de Concepción, Facultad de Agronomía, Avenida Vicente Méndez 595, Chillán, Chile.

${ }^{2}$ Universidad de Talca, Facultad de Ciencias Agrarias, Avenida Lircay S/N, Talca, Chile.

${ }^{3}$ Hortifrut S.A., Avenida del Cóndor 600, Huechuraba, Santiago, Chile. ${ }^{4}$ Instituto de Investigaciones Agropecuarias, INIA Quilamapu, Avenida Vicente Méndez 515, Chillán, Chile.

*Corresponding author (jhirzel@inia.cl).

Received: 16 September 2015.

Accepted: 13 January 2016.

doi:10.4067/S0718-58392016000200010

\section{INTRODUCTION}

The first blueberry (Vaccinium corymbosum L.) plants were introduced in Chile during the $80 \mathrm{~s}$ to evaluate its potential in the region. Since then, blueberry production has grown very quickly with the largest plantation areas concentrated in central and southern Chile (Bañados, 2006). It has been determined that blueberries reach their maximum production potential when certain factors are controlled, such as planting density (Strik and Buller, 2005), variety (Bryla and Strik, 2007), irrigation management (Bryla et al., 2006), fertilization (Hanson, 2006), weed control (Krewer et al., 2009), and pH (Burkhard et al., 2009). According to Strik (2014), there were 77290 ha of blueberries worldwide in 2010, mainly in the USA (46\%) followed by Chile $(17 \%)$. The same author reports that the area of organically-grown blueberries was 4156 ha in the USA and 1600 ha in Chile.

Organic farming techniques to grow crops have gained popularity in recent years as a result of an increasing consumer demand for organic products and farmers' commitment to soil conservation (Brazelton and Strik, 2007; Larco et al., 2013). According to Lester (2006), the production of organic food is steadily growing due to a higher demand for this type of food, which dates back to 1900; the main markets are the USA and Germany. Despite this increasing demand, there are still many problems when comparing nutrient sources in organic and conventional farming systems, mainly because of the difficulty to control all the variables involved (Lester, 2006).

Soil total N content under organic management increases steadily when fertilization is applied; it also increases by incorporating cover crops, peat, compost, fishmeal, humus, and N-rich fertilizers due to the accumulation of both $\mathrm{N}$ and $\mathrm{C}$ in organic compounds (Wang et al., 2008). These natural nutrients promote the growth of beneficial soil microorganisms, decompose biomass, and indirectly provide $\mathrm{N}, \mathrm{P}, \mathrm{K}$, and other nutrients available to plants through the crop rhizosphere (Wang et al., 2008). The mixture of livestock manure and bedding straw can be a suitable nutrient source for blueberries. The nutrient content of manure should be well estimated to determine proper application rates. Nevertheless, the nutrient composition of manure varies depending on the animal species and other variables, such as management and handling, which do not allow homogeneous applications (Kozinski, 2006; Larco, 2010; Larco et al., 2013).

After crops have been established, the major concern in organic production is the application of $\mathrm{N}$ sources because $\mathrm{N}$ availability is highly related to productivity (Miller et al., 2006). Organic 
fertilizers are usually less soluble than inorganic fertilizers . Based on this, organic fertilizers should be applied 1 to 4 wk earlier than the recommended time for the application of inorganic fertilizers (soluble) (Gale et al., 2006). All ammoniacal $\mathrm{N}$ and $25 \%$ to $50 \%$ of organic $\mathrm{N}$ is available for blueberry plants during the same year it is applied. Therefore, $\mathrm{N}$ rates should be increased by $50 \%$ to $100 \%$ when organic materials are used because microorganisms fix a significant fraction of N (Bañados et al., 2012; Vargas and Bryla, 2015). Regarding this, other authors have indicated that despite a slower release of organic $\mathrm{N}$ sources, remaining $\mathrm{N}$ from previous seasons provides residual $\mathrm{N}$ release similar to the amount of $\mathrm{N}$ applied in every season (Retamales and Hancock, 2012).

The main sources of $\mathrm{N}$ for organic farming are compost, green manures, natural fertilizers, and residues from biological processes, so that total $\mathrm{N}$ release in plant-available forms is related to the mineralization capacity of the soil along with nutritional factors (energy, $\mathrm{C}$ and $\mathrm{N}$ content, among others) and soil factors (temperature, moisture, oxygen, acidity) as reported by several authors (Tamada, 2004; Hanson, 2006; Bañados et al., 2012; Hirzel et al., 2012; Retamales and Hancock, 2012). When the required data is collected, prediction equations can be used to determine the release of $\mathrm{N}$ and other nutrients. Therefore, based on the lack of information about the nutritional management of organic $\mathrm{N}$ in blueberries, a study was conducted to determine vegetative, nutritional, and productive response to different organic $\mathrm{N}$ sources of three different early-, mid-, and latefruiting blueberry cultivars.

\section{MATERIALS AND METHODS}

An experiment was established on 15 October 2011 and conducted in Los Ángeles ( $37^{\circ} 26^{\prime}$ S, 72 $31^{\circ}$ ' W, 103 m a.s.1.) in the Biobío Region, Chile. Mean annual rainfall reaches $1093 \mathrm{~mm}$ and there is a 5-mo dry period. Summers are warm and winters are moderately cold with a frost-free period of $235 \mathrm{~d}$ and a mean of nine annual frosts. Annual degree-days reach 1593 while chilling hours reach 1237.

Meristematic plants were planted in 50-L pots with a density of 5000 plants ha-1, which was higher than the $5 \mathrm{~L}$ volume used by Crisóstomo et al. (2014). Pot soil was sandy loam composed of $40.5 \%$ sand, $43.2 \%$ silt, and $16.3 \%$ clay (Aquic Haploxerolls, CIREN, 1999). It had 5.6\% organic matter and 6.16 water $\mathrm{pH}$. Contents of $\mathrm{N}, \mathrm{P}, \mathrm{K}$, and $\mathrm{S}$ were $31,13,187$, and $12.8 \mathrm{mg} \mathrm{kg}^{-1}$, respectively (Sadzawka et al., 2004). Water reposition during spring and summer was conducted with an irrigation system using two emitters of $2.1 \mathrm{~L}^{-1}$ each per plant, which was based on $66 \%$ reposition of daily evapotranspiration (Holzapfel et al., 2004); there were three irrigation events per week of $2 \mathrm{~h} \mathrm{~d}^{-1}$ for 6 mo (October to March) for a total of $300 \mathrm{~mm}$ of irrigation per season. To determine evapotranspiration, an evaporation pan reference was located on the experimental site.

Three varieties of blueberries were evaluated: 'Corona', 'Legacy', and 'Liberty'. These varieties are early-, mid-, and late-fruiting, respectively, in this agro-climatic zone. Flower buds were removed in the first year to avoid fruit production in the first season. The following treatments were applied during the 2011-2012, 2012-2013, and 2013-2014 seasons: 1) No fertilizer application (C) as an indicator of soil nutrient supply, 2) local compost $(\mathrm{CM})\left(\mathrm{N}: \mathrm{P}_{2} \mathrm{O}_{5}: \mathrm{K}_{2} \mathrm{O}\right.$; 0.84:0.80:0.45 and $\mathrm{C}: \mathrm{N}$ ratio 11.96) as powder, 3) Fertil (F) $\left(\mathrm{N}: \mathrm{P}_{2} \mathrm{O}_{5}: \mathrm{K}_{2} \mathrm{O} ; 12.0: 0.0: 0.0\right.$ and $\mathrm{C}: \mathrm{N}$ ratio 7.60) as pellets, 4) Purely Grow (PG) $\left(\mathrm{N}_{2} \mathrm{P}_{2} \mathrm{O}_{5}: \mathrm{K}_{2} \mathrm{O} ; 13.1: 0.0: 4.0\right.$ and $\mathrm{C}: \mathrm{N}$ ratio 6.20) as liquid, 5) Purely Lysine (PL) $\left(\mathrm{N}: \mathrm{P}_{2} \mathrm{O}_{5}: \mathrm{K}_{2} \mathrm{O}\right.$; 15.5:0.0:0.0 and $\mathrm{C}: \mathrm{N}$ ratio 5.80) as pellets, 6) sodium nitrate (S) $\left(\mathrm{N}: \mathrm{P}_{2} \mathrm{O}_{5}: \mathrm{K}_{2} \mathrm{O} ; 15.0: 0.0: 9.0\right)$ as granules, 7) blood meal (BM) ( $\mathrm{N}: \mathrm{P}_{2} \mathrm{O}_{5}: \mathrm{K}_{2} \mathrm{O} ; 14.5: 0.27: 0.6$ and $\mathrm{C}: \mathrm{N}$ ratio 3.74) as powder, 8) lupine meal (LM) $\left(\mathrm{N}_{2} \mathrm{P}_{2} \mathrm{O}_{5}: \mathrm{K}_{2} \mathrm{O} ; 7.93: 0.90: 1.00\right.$ and $\mathrm{C}: \mathrm{N}$ ratio 5.67) as broken grain, and 9) urea, triple superphosphate, and potassium sulfate $(\mathrm{CF})\left(\mathrm{N}: \mathrm{P}_{2} \mathrm{O}_{5}: \mathrm{K}_{2} \mathrm{O}\right.$; 45.0:15.8:29.7) as granules. Total $\mathrm{N}$ rates were calculated for $80 \mathrm{~kg} \mathrm{ha}^{-1}$ rate in the first year and $100 \mathrm{~kg} \mathrm{ha}^{-1}$ in years 2 and 3 . The indicated $\mathrm{N}$ rate was divided into three fractions (except for compost application) and applied in early October (50\%) (beginning of vegetative growth), early December (25\%) (60\% to $70 \%$ vegetative growth), and at the end of January (25\%) (80\% to $90 \%$ vegetative growth). Compost was not split because this organic fertilizer is applied only once in a real management situation and its $\mathrm{N}$ mineralization is slow (Hirzel et al., 2012). For CF, $\mathrm{P}$ and $\mathrm{K}$ were applied at rates of 35 and $66 \mathrm{~kg} \mathrm{ha}^{-1} \mathrm{P}_{2} \mathrm{O}_{5}$ and $\mathrm{K}_{2} \mathrm{O}$, respectively (Bañados et al., 2012), which also allowed generating conditions without limiting these nutrients in accordance with the soil chemical properties used in this study. Fertilizers were applied at a distance from the blueberry plants and delineated a peripheral ring. Technical information about the $\mathrm{N}$ release speed of the evaluated fertilizers has been presented by Hirzel (2014); this report indicated that release to $\mathrm{CF}$ was fast for $\mathrm{S}, \mathrm{PG}$, $\mathrm{PL}$, and $\mathrm{F}$ while there was medium release to LM and BM and slow release to CM.

Leaves were collected in May of each year during the dormant period or close to abscission based on field observations to determine both DM and $\mathrm{N}$ accumulation prior to leaf fall as an indicator of $\mathrm{N}$ recovery efficiency in each treatment. These samples were weighed to determine fresh weight and leaf development of each variety. In addition, each sample was dried in an oven at $70{ }^{\circ} \mathrm{C}$ to constant weight and the dry weight of each sample was determined. A subsample of each tissue was ground and sieved through a 40 mesh sieve (0.42 mm openings) to measure the concentrations of total $\mathrm{N}$ by acid digestion and Kjeldahl distillation and titration. Leaf $\mathrm{N}$ extraction was determined by its $\mathrm{DM}$ and $\mathrm{N}$ concentration $\left(\mathrm{N}\right.$ extraction $=\mathrm{DM}\left(\mathrm{g}\right.$ plant $\left.\mathrm{t}^{-1}\right) \times \mathrm{N}$ concentration $\left.(\% / 100)\right)$. A SPAD-502 instrument (Minolta, Spectrum Technologies, Plain Field, Illinois, USA) was used in December 2013 to measure the level of chlorophyll present in leaves of third medium of each treatment in the three varieties under study. This measurement was taken at 11:00 h. During May 2013 and 2014, both the number and length of basal shoots were determined. The number of lateral shoots and the sum of their lengths were also determined to estimate 
plant vegetative growth. Plants were pruned during winter dormancy in 2012 and 2013. All fruit buds were removed in 2012, and pruning in 2013 was done using the equilibrium between both vegetative and reproductive bud as a guideline, which allowed appropriate vegetative development and productivity. In 2013, pruning after the first year of fruit production was conducted so that flower buds were left for fruit production according to the vegetative development of each treatment.

'Corona', 'Legacy', and 'Liberty' blueberries were collected manually. Fruit yield, weight, and size were determined at harvest from December 2013 to February 2014 in accordance with fruit ripeness. Fruit color was used as the harvest index. A randomized complete block design with a split-plot arrangement was used; the main plot was the cultivar and the subplot was the $\mathrm{N}$ source with four replicates per treatment, one plant per pot, and three plants per experimental unit. The season was considered as an independent variable, so statistical analysis between seasons was not considered. ANOVA, mean separation test (Tukey), and separation of interactions by contrasts were performed at the 5\% significance level with SAS 6.0 (SAS Institute, Cary, North Carolina, USA). Contrast analyses were used to separate the interactions.

\section{RESULTS}

All evaluated parameters were affected by the cultivar $(\mathrm{p}<$ 0.001 ), with the exception of leaf $\mathrm{N}$ concentration that was estimated in February 2012 (Table 1). Similarly, N sources also affected all the evaluated parameters $(\mathrm{p}<0.001$ and $\mathrm{p}<$ 0.01 ), with the exception of the number of basal shoots per plant that was determined in the 2012-2013 season (Table 1). Significant effects were observed in the cultivar $\times \mathrm{N}$ source interaction with respect to the sum of lengths of lateral and basal shoots in the 2013-2014 season and fruit weight from the first harvest $(\mathrm{p}<0.05)$ (Table 1$)$. In addition, highly significant effects $(\mathrm{p}<0.01$ and $\mathrm{p}<0.001)$ were observed in the Cultivar $\times \mathrm{N}$ Source interaction with respect to leaf $\mathrm{N}$ concentration in February 2012, number of lateral shoots per plant in the 2012-2013 season, sum of lengths of lateral shoots in the 2012-2013 season, leaf dry weight in May 2013, leaf N extraction in May 2013, SPAD units measured in December 2013 , fruit yield in the first harvest, leaf $\mathrm{N}$ concentration in February 2014, leaf dry weight in May 2014, and leaf $\mathrm{N}$ extraction in May 2014 (Table 1). Interactions generally responded to differences between cultivars and $\mathrm{N}$ sources, which were separated by contrast analysis. These variability effects are explained by the $\mathrm{N}$ source in most of the evaluated parameters (Tables 2 and 3, Figures 1, 2, 3, and 4).

The number of evaluated basal shoots in the 2012-2013 season was higher in 'Liberty' with 4.6 basal shoots ( $\mathrm{p}<$ 0.05 ) followed by 'Legacy' and 'Corona' with 3.8 and 3.5 basal shoots, respectively (Table 2). The sum of lengths of all basal shoots during the 2012-2013 season was higher in 'Liberty' and 'Legacy' ( $\mathrm{p}<0.05$ ) with values of 184.8 and $167.2 \mathrm{~cm}$ plant $^{-1}$, respectively; the value recorded in 'Corona' was lower ( $<$ < 0.05) and reached $129.5 \mathrm{~cm} \mathrm{plant}^{-1}$ (Table 2). Regarding N sources, LM had the highest value for the sum of lengths of basal shoots with a mean value of $218.3 \mathrm{~cm}$ plant $^{-1}$. This value was higher than those recorded in $\mathrm{C}$ and PG $(\mathrm{p}<0.05)$ with mean values that reached 130.1 and 135.9 $\mathrm{cm}$ plant ${ }^{-1}$, respectively (Table 3 ).

The highest number of lateral shoots per plant was recorded by 'Corona' ( $\mathrm{p}<0.05$ ) followed by 'Liberty' ( $\mathrm{p}<$ $0.05)$ and 'Legacy' for the 2012-2013 season with values of $34.6,17.9$, and 12.4 shoots plant $^{-1}$, respectively (Table 2 ). The highest $\mathrm{N}$ source values were obtained by using F, PG, PL,

Table 1. Significance analysis of parameters for vegetative and nutritional growth evaluated in 'Corona', 'Legacy' and 'Liberty' blueberries with different $N$ sources during the 2012-2013 and 2013-2014 seasons.

\begin{tabular}{|c|c|c|c|}
\hline Source of variation & $\begin{array}{l}\text { Cultivars } \\
\text { (C) }\end{array}$ & $\begin{array}{l}\text { Nitrogen sources } \\
\text { (N) }\end{array}$ & $\begin{array}{c}\text { Interaction } \\
(\mathrm{C} \times \mathrm{N})\end{array}$ \\
\hline Leaf $\mathrm{N}$ concentration, $\mathrm{g} \mathrm{kg}^{-1}$ (February 2012) & NS & $* * *$ & $* *$ \\
\hline Leaf dry weight, g plant ${ }^{-1}$ (May 2012) & $* * *$ & $* * *$ & NS \\
\hline Leaf $\mathrm{N}$ extraction, $\mathrm{mg}_{\text {plant }}{ }^{-1}$ (May 2012) & $* * *$ & $* * *$ & NS \\
\hline Number of lateral shoots per plant, 2012-2013 & $* * *$ & $* * *$ & $* *$ \\
\hline Number of basal shoots per plant, 2012-2013 & $* *$ & NS & NS \\
\hline Sum $(\mathrm{cm})$ of the lengths of lateral shoots, $\mathrm{cm} \mathrm{plant}^{-1}(2012-2013)$ & $* * *$ & $* * *$ & $* * *$ \\
\hline Sum of the lengths of basal shoots, $\mathrm{cm}$ plant $^{-1}(2012-2013)$ & $* * *$ & $* *$ & NS \\
\hline Leaf $\mathrm{N}$ concentration, $\mathrm{g} \mathrm{kg}^{-1}$ (May 2013) & $* * *$ & $* * *$ & NS \\
\hline Leaf dry weight, g plant $^{-1}$ (May 2013) & $* * *$ & $* * *$ & $* * *$ \\
\hline Leaf $\mathrm{N}$ extraction, $\mathrm{mg}$ plant $^{-1}$ (May 2013) & $* * *$ & $* * *$ & $* * *$ \\
\hline SPAD (unit), December 2013 & $* * *$ & $* * *$ & $* * *$ \\
\hline Number of lateral shoots per plant, 2013-2014 & $* * *$ & $* * *$ & NS \\
\hline Number of basal shoots per plant, 2013-2014 & $* * *$ & $* * *$ & NS \\
\hline Sum $(\mathrm{cm})$ of the lengths of lateral shoots 2013-2014 & $* * *$ & $* * *$ & $*$ \\
\hline Sum $(\mathrm{cm})$ of the lengths of basal shoots $2013-2014$ & $* * *$ & $* * *$ & $*$ \\
\hline Fruit weight, $g$ & $* * *$ & $* *$ & $*$ \\
\hline Yield, g plant $^{-1}$ & $* * *$ & $* * *$ & ** \\
\hline Leaf $\mathrm{N}$ concentration, $\mathrm{g} \mathrm{kg}^{-1}$, (May 2014) & $* * *$ & $* * *$ & $* * *$ \\
\hline Leaf dry weight, g plant ${ }^{-1}$, (May 2014) & $* * *$ & $* * *$ & $* * *$ \\
\hline Leaf $\mathrm{N}$ extraction, $\mathrm{mg}$ plant $^{-1}$ (May 2014) & $* * *$ & $* * *$ & $* * *$ \\
\hline
\end{tabular}

$*, * *, * * *$ Significant at probability levels of $0.05,0.01$, and 0.001 . NS: nonsignificant. 
Table 2. Vegetative and nutritional growth parameters of 'Corona', 'Legacy', and 'Liberty' blueberries in the $2012-2013$ and 2013 2014 seasons.

\begin{tabular}{|c|c|c|c|c|c|}
\hline & $\begin{array}{c}\text { Basal shoots } \\
\text { per plant }\end{array}$ & $\begin{array}{l}\text { Sum of length } \\
\text { of basal shoots }\end{array}$ & $\begin{array}{l}\text { Lateral shoots } \\
\text { per plant }\end{array}$ & $\begin{array}{l}\text { Sum of length } \\
\text { of lateral shoots }\end{array}$ & $\begin{array}{l}\text { SPAD units } \\
\text { (December) }\end{array}$ \\
\hline Cultivar & nr plant $^{-1}$ & $\mathrm{~cm}_{\text {plant }}{ }^{-1}$ & nr plant ${ }^{-1}$ & $\mathrm{~cm}_{\text {plant }}{ }^{-1}$ & Units \\
\hline \multicolumn{6}{|c|}{ 2012-2013 Season } \\
\hline Corona & $3.5 b$ & $129.5 b$ & $34.6 \mathrm{a}$ & $436.9 a$ & $50.3 \mathrm{a}$ \\
\hline Legacy & $3.8 \mathrm{~b}$ & $167.2 \mathrm{a}$ & $12.4 \mathrm{c}$ & $230.1 \mathrm{c}$ & $47.0 \mathrm{~b}$ \\
\hline Liberty & $4.6 \mathrm{a}$ & $184.8 \mathrm{a}$ & $17.9 \mathrm{~b}$ & $312.6 b$ & $39.7 \mathrm{c}$ \\
\hline \multicolumn{6}{|c|}{ 2013-2014 Season } \\
\hline Corona & $3.0 \mathrm{~b}$ & $196.9 b$ & $59.3 \mathrm{a}$ & $732.8 \mathrm{a}$ & $\mathrm{Nd}$ \\
\hline Legacy & $5.5 \mathrm{a}$ & $306.9 a$ & $35.1 b$ & $477.6 b$ & $\mathrm{Nd}$ \\
\hline Liberty & $6.4 \mathrm{a}$ & $337.8 \mathrm{a}$ & $37.0 \mathrm{~b}$ & $433.3 b$ & $\mathrm{Nd}$ \\
\hline
\end{tabular}

Different letters in the columns for the same season indicate differences among cultivars according to Tukey's test ( $\mathrm{p}<0.05$ ).

Nd: Not determined; nr: number.

Table 3. Parameters of vegetative and nutritional growth according to the different $\mathrm{N}$ treatments used in the 2012-2013 and 2013 2014 seasons.

\begin{tabular}{|c|c|c|c|c|c|}
\hline & $\begin{array}{l}\text { Basal shoots } \\
\text { per plant }\end{array}$ & $\begin{array}{l}\text { Sum of length } \\
\text { of basal shoots }\end{array}$ & $\begin{array}{l}\text { Lateral shoots } \\
\text { per pla }\end{array}$ & $\begin{array}{l}\text { Sum of length } \\
\text { of lateral shoots }\end{array}$ & $\begin{array}{l}\text { SPAD units } \\
\text { (December) }\end{array}$ \\
\hline Treatment & nr plant ${ }^{-1}$ & $\mathrm{~cm}_{\text {plant }}{ }^{-1}$ & $\mathrm{nr}_{\text {plant }}{ }^{-1}$ & $\mathrm{~cm}_{\text {plant }}{ }^{-1}$ & Units \\
\hline \multicolumn{6}{|c|}{ 2012-2013 Season } \\
\hline $\mathrm{C}$ & $3.3 \mathrm{a}$ & $130.1 b$ & $19.0 \mathrm{ab}$ & $242.8 \mathrm{bc}$ & $37.4 \mathrm{de}$ \\
\hline $\mathrm{CM}$ & $4.0 \mathrm{a}$ & $158.4 \mathrm{ab}$ & $17.7 \mathrm{ab}$ & $225.8 \mathrm{bc}$ & $34.8 \mathrm{e}$ \\
\hline $\mathrm{F}$ & $4.6 \mathrm{a}$ & $178.8 \mathrm{ab}$ & $24.2 \mathrm{a}$ & $354.1 \mathrm{ab}$ & $45.9 \mathrm{bc}$ \\
\hline PG & $3.6 \mathrm{a}$ & $135.9 \mathrm{~b}$ & $23.1 \mathrm{a}$ & $310.8 \mathrm{abc}$ & $50.1 \mathrm{ab}$ \\
\hline PL & $4.3 \mathrm{a}$ & $160.0 \mathrm{ab}$ & $24.6 \mathrm{a}$ & $373.3 \mathrm{ab}$ & $43.7 \mathrm{c}$ \\
\hline $\mathrm{S}$ & $4.1 \mathrm{a}$ & $171.3 \mathrm{ab}$ & $11.0 \mathrm{~b}$ & $198.3 \mathrm{c}$ & $40.6 \mathrm{~cd}$ \\
\hline BM & $4.2 \mathrm{a}$ & $154.0 \mathrm{ab}$ & $24.8 \mathrm{a}$ & $363.7 \mathrm{ab}$ & $51.3 \mathrm{ab}$ \\
\hline LM & $4.6 \mathrm{a}$ & $218.3 \mathrm{a}$ & $24.2 \mathrm{a}$ & $420.5 \mathrm{a}$ & $52.2 \mathrm{a}$ \\
\hline $\mathrm{CF}$ & $3.3 \mathrm{a}$ & $137.5 b$ & $26.3 \mathrm{a}$ & $449.5 \mathrm{a}$ & $54.2 \mathrm{a}$ \\
\hline \multicolumn{6}{|c|}{ 2013-2014 Season } \\
\hline $\mathrm{C}$ & $3.8 \mathrm{~d}$ & $186.0 \mathrm{c}$ & $29.8 \mathrm{c}$ & $311.2 \mathrm{~cd}$ & $\mathrm{Nd}$ \\
\hline $\mathrm{CM}$ & 4.4abcd & $226.5 \mathrm{bc}$ & $26.3 \mathrm{c}$ & $337.1 \mathrm{~cd}$ & $\mathrm{Nd}$ \\
\hline $\mathrm{F}$ & $6.5 \mathrm{a}$ & $388.7 \mathrm{a}$ & $48.4 \mathrm{abc}$ & $661.7 \mathrm{abc}$ & $\mathrm{Nd}$ \\
\hline PG & $4.0 \mathrm{~cd}$ & $198.4 \mathrm{c}$ & $38.4 \mathrm{bc}$ & $416.0 \mathrm{~cd}$ & $\mathrm{Nd}$ \\
\hline PL & $6.0 \mathrm{abc}$ & $348.3 \mathrm{ab}$ & $49.3 \mathrm{abc}$ & $591.1 \mathrm{bcd}$ & $\mathrm{Nd}$ \\
\hline $\mathrm{S}$ & 4.8abcd & $222.0 \mathrm{bc}$ & $24.3 \mathrm{c}$ & $256.1 \mathrm{~d}$ & $\mathrm{Nd}$ \\
\hline $\mathrm{BM}$ & 4.8abcd & $308.3 \mathrm{abc}$ & $61.0 \mathrm{ab}$ & $782.2 \mathrm{ab}$ & $\mathrm{Nd}$ \\
\hline LM & $6.2 \mathrm{ab}$ & $416.3 \mathrm{a}$ & $71.1 \mathrm{a}$ & $1023.8 \mathrm{a}$ & $\mathrm{Nd}$ \\
\hline $\mathrm{CF}$ & $4.3 \mathrm{bcd}$ & $230.4 \mathrm{bc}$ & $45.8 \mathrm{abc}$ & $552.4 \mathrm{bcd}$ & $\mathrm{Nd}$ \\
\hline
\end{tabular}

Different letters in the columns for the same season indicate differences between $\mathrm{N}$ fertilization treatments according to Tukey's test ( $\mathrm{p}<0.05)$.

Nd: Not determined; nr: number.

BM, LM, and CF. Values showed no significant differences among them $(\mathrm{p}>0.05)$ and were only higher than the value obtained for $\mathrm{S}(\mathrm{p}<0.05)$ (Table 3$)$.

The values of the sum of lengths of lateral shoots for 20122013 were $436.9,312.6$, and $230.1 \mathrm{~cm}$ plant $^{-1}$, from highest to lowest, for 'Corona', 'Liberty', and 'Legacy' ( $\mathrm{p}<0.05$ ), respectively (Table 2). For N sources, LM and CF treatments had the highest values for this parameter $(\mathrm{p}<0.05)$ with mean values of 420.5 and $449.5 \mathrm{~cm} \mathrm{plant}^{-1}$, respectively. Values showed nonsignificant differences $(p>0.05)$ and were only higher than those obtained for $\mathrm{C}, \mathrm{CM}$, and $\mathrm{S}(\mathrm{p}<0.05)$ with $242.8,225.8$, and $198.3 \mathrm{~cm} \mathrm{plant}^{-1}$, respectively (Table 3).

For the number of basal shoots per plant in the 2013-2014 season, 'Liberty' and 'Legacy' recorded the highest values (6.4 and 5.5, respectively). Values showed nonsignificant differences among them $(\mathrm{p}>0.05)$ and were higher than the value for 'Corona' $(\mathrm{p}<0.05)$ that reached 3.0 (Table 2$)$. The highest value for $\mathrm{N}$ sources (Table 3 ) was obtained using $F(6.5)$. This value was significantly higher $(p<0.05)$ than the values for $\mathrm{CF}, \mathrm{PG}$, and $\mathrm{C}$, which showed no differences among them $(\mathrm{p}>0.05)$.

For the sum of lengths of basal shoots during the 20132014 season, the highest values were observed in 'Liberty' and 'Legacy' ( $p<0.05)$. There was no difference between these values $(\mathrm{p}>0.05)$ of 337.8 and $306.9 \mathrm{~cm} \mathrm{plant}^{-1}$, respectively. 'Corona' had a lower value $(\mathrm{p}<0.05)$ of 196.9 $\mathrm{cm}$ plant $^{-1}$ (Table 2). Treatments LM, F, PL, and BM for N sources showed the highest values for the sum of lengths of basal shoots of 416.3, 388.7, 348.3, and $308.3 \mathrm{~cm} \mathrm{plant}{ }^{-1}$, respectively (Table 3 ). Only the values for LM and F were higher than those for the other evaluated treatments $(\mathrm{p}<0.05)$. There was a similarity between PL and C, CF, and S ( $p>0.05)$ while BM was similar to C, CO, S, CF, and PG ( $\mathrm{p}>0.05)$.

When comparing cultivars, the number of lateral shoots per plant in the 2012-2014 season ranged from 35.1 to 59.3. The highest value was obtained for 'Corona' ( $p<0.05$ ) followed by 'Liberty' and 'Legacy' without any differences between them $(\mathrm{p}>0.05)$ (Table 2$)$. Values for $\mathrm{N}$ sources 
ranged from 24.3 to 71.1 (Table 3 ). The highest values were obtained when using LM, BM, PL, F, and CF and with nonsignificant differences between them $(\mathrm{p}>0.05)$. Nevertheless, only the LM application resulted in higher values than those obtained for $\mathrm{PG}, \mathrm{S}, \mathrm{CO}$, and $\mathrm{C}(\mathrm{p}<0.05)$. Similarly, BM had higher values than those obtained for $\mathrm{S}$, $\mathrm{CM}$, and $\mathrm{C}(\mathrm{p}<0.05)$ (Table 3$)$.

For the sum of lengths of lateral shoots in the 2013-2014 season, the highest value was obtained for 'Corona' ( $\mathrm{p}<$ $0.05)$ with $732.8 \mathrm{~cm} \mathrm{plant}^{-1}$, while values for 'Legacy' and 'Liberty' had nonsignificant differences between them ( $p$ $>0.05$ ) and were 477.6 and $433.3 \mathrm{~cm} \mathrm{plant}^{-1}$, respectively (Table 2). As for $\mathrm{N}$ sources, the LM, BM, and F treatments showed the highest values for the sum of the lengths of lateral shoots (Table 3). There were nonsignificant differences between these values $(p>0.05)$ of $1023.8,782.7$, and $661.7 \mathrm{~cm} \mathrm{plant}^{-1}$, respectively. Only the values for LM were significantly higher than those obtained with the other evaluated treatments $(\mathrm{p}<0.05)$. Blood meal was significantly higher than $\mathrm{C}, \mathrm{CO}, \mathrm{PG}$, and $\mathrm{S}(\mathrm{p}<0.05)$ while $\mathrm{F}$ was only significantly higher than $\mathrm{S}(\mathrm{p}>0.05)$ (Table 3$)$.

There were differences between cultivars for SPAD units. Values of 50.3, 47.0, and 39.7, from highest to lowest, were for 'Corona', 'Legacy', and 'Liberty' ( $\mathrm{p}<0.05$ ), respectively (Table 2). For N sources, the highest values were obtained for CF, LM, BM, and PG. Values did not show any significant differences ( $p>0.05$ ); these were 54.2, 52.2, 51.3, and 50.1, respectively (Table 3 ). For CF and LM, values were higher than for C, CM, F, PL, and S ( $\mathrm{p}<0.05$ ) while those for BM and $\mathrm{PG}$ were significantly higher than the results obtained for C, CO, PL, and S (p < 0.05) (Table 3).

Leaf DM production prior to leaf fall in the three seasons was generally higher in 'Corona' followed by 'Legacy' and 'Liberty', but nonsignificant differences were found between cultivars ( $\mathrm{p}>0.05$ ) (Figures 1a, 1c, and 1e). Recorded values were $15.96,7.10$, and $6.65 \mathrm{~g} \mathrm{plant}^{-1}$ in the 2011-2012 season; 25.76, 18.46, and $14.83 \mathrm{~g} \mathrm{plant}^{-1}$ in the 2012-2013 season; 102.56, 65.66, and $31.64 \mathrm{~g} \mathrm{plant}^{-1}$ in the 2013-2014 season for 'Corona', 'Legacy', and 'Liberty', respectively (Figures 1a, 1c, and 1e). For the 2011-2012 season, values ranged from 3.48 to $12.66 \mathrm{~g} \mathrm{plant}^{-1}$ while the highest leaf DM production was observed using F, CM, PG, PL, BM, and $\mathrm{CF}$, which was only higher than the value obtained for $\mathrm{S}(\mathrm{p}<0.05)$ (Figure 1b). For the 2012-2013 season, values ranged from 14.84 to $26.91 \mathrm{~g}$ plant $^{-1}$ while the highest leaf DM production was obtained using LM. This value was higher than those obtained for C, CM, F, S, and BM ( p < 0.05) (Figure 1d). For the 2013-2014 season, values ranged from 28.15 to $121.20 \mathrm{~g} \mathrm{plant}^{-1}$ while the highest leaf DM production was also obtained using LM, which was only higher than values obtained for C, CM, PG, PL, S, and CF ( $\mathrm{p}$ $<0.05$ ) (Figure 1f).

Leaf $\mathrm{N}$ concentration prior to leaf fall showed differences between seasons for each evaluated cultivar associated with the interaction between sources of variation (Table 1 and Figures 2a, 2c, and 2e). Values for this parameter ranged from 15.57 to $16.61 \mathrm{~g} \mathrm{~kg}^{-1}$ in the $2011-2012$ season and showed nonsignificant differences $(\mathrm{p}>0.05)$ (Figure 2a). For the 2012-2013 season, values ranged from 12.60 to $17.64 \mathrm{~g} \mathrm{~kg}^{-1}$ with the highest value recorded for 'Corona' $(\mathrm{p}<0.05)$ and with no differences between 'Legacy' and 'Liberty' ( $p>0.05$ ) (Figure 2c). For the 2013-2014 season, leaf $\mathrm{N}$ concentration ranged from 6.26 to $11.26 \mathrm{~g} \mathrm{~kg}^{-1}$. In this case, values from the highest to the lowest, were for 'Corona', 'Legacy', and 'Liberty' ( $\mathrm{p}<0.05$ ), respectively (Figure 2e). Results for the effects of $\mathrm{N}$ sources showed differences between seasons, which were associated with the interaction between sources of variation (Table 1, Figures $2 \mathrm{~b}, 2 \mathrm{~d}$, and 2f). For the 2011-2012 season, values ranged from 10.68 to $20.26 \mathrm{~g} \mathrm{~kg}^{-1}$. The highest $\mathrm{N}$ concentration was achieved for $\mathrm{CF}$, which was only higher than values obtained for C, CM, F, S, BM, and LM (p < 0.05) (Figure 2b). For the 2012-2013 season, values ranged from 8.44 to $20.88 \mathrm{~g}$ $\mathrm{kg}^{-1}$ and the highest leaf $\mathrm{N}$ concentration was achieved using $\mathrm{PL}$, which was only higher than the values obtained for $\mathrm{C}$, CM, F, S, BM, FL, and CF ( $<$ 0.05) (Figure 2d). For the 2013-2014 season, values ranged from 6.11 to $12.40 \mathrm{~g} \mathrm{~kg}^{-1}$ and the highest leaf $\mathrm{N}$ concentration was achieved using $\mathrm{CF}$, $\mathrm{F}$, and $\mathrm{PG}$, which was only significantly higher than values obtained for C, CM, PL, and S ( $<<0.05)$ (Figure 2f).

When evaluating each cultivar, $\mathrm{N}$ extraction prior to leaf fall showed differences between seasons associated with the interaction between sources of variation (Table 1 and Figures 3a, 3c, and 3e). For the 2011-2012 season, leaf $\mathrm{N}$ extraction values varied between 100 and $260 \mathrm{mg} \mathrm{plant}^{-1}$ and the highest value was obtained for 'Corona' $(\mathrm{p}<0.05)$. No differences were found between 'Legacy' and 'Liberty' ( $p>0.05)$ (Figure $3 a)$. For the 2012-2013 season, leaf $\mathrm{N}$ extraction was between 200 and $450 \mathrm{mg}$ plant $^{-1}$ and the highest to lowest values were for 'Corona', 'Legacy', and 'Liberty' ( $p<0.05$ ), respectively (Figure 3c). For the 2013-2014 season, this parameter varied between 200 and $1370 \mathrm{mg}$ plant $^{-1}$ while the highest to lowest values were for 'Corona', 'Legacy', and 'Liberty' $(\mathrm{p}<0.05)$, respectively (Figure $3 \mathrm{e}$ ). The effects of $\mathrm{N}$ sources showed differences between seasons (Table 1, Figures 3b, 3d, and $3 f)$. For the 2011-2012 season, values were between 60 and $240 \mathrm{mg} \mathrm{plant}^{-1}$ and the highest $\mathrm{N}$ extraction was achieved using PL, F, PG, and CF, which was only higher than the values obtained for $\mathrm{C}, \mathrm{CM}$, and $\mathrm{S}(\mathrm{p}<0.05)$ (Figure $3 \mathrm{~b}$ ). For the 2012-2013 season, values were between 130 and 450 $\mathrm{mg} \mathrm{plant}^{-1}$ the same as for the 2011-2012 season when the highest leaf $\mathrm{N}$ extraction was achieved using PL, F, PG, and $\mathrm{CF}$, which only exceeded the values obtained for C, CM, and $\mathrm{S}(\mathrm{p}<0.05)$ (Figure 3d). For the season 2013-2014, values varied between 150 and $1400 \mathrm{mg}$ plant $^{-1}$ and the highest leaf $\mathrm{N}$ extraction was obtained using LM and F, which was only higher than the values obtained for $\mathrm{C}, \mathrm{CM}, \mathrm{PG}, \mathrm{PL}$, and $\mathrm{S}$ ( $\mathrm{p}$ $<0.05$ ) (Figure 3f).

Fruit production in the 2013-2014 season (first crop production season) ranged from 128.29 to $264.92 \mathrm{~g} \mathrm{plant}^{-1}$ (Figure 4); the highest yield was obtained for 'Corona' ( $p$ $<0.05)$ followed by 'Legacy' and 'Liberty'; there were no differences between them $(\mathrm{p}>0.05)$. The effects of $\mathrm{N}$ sources on fruit yield (Table 1, Figures $4 \mathrm{~b}$ ) resulted in values 
Figure 1. Leaf dry matter (DM) production prior to leaf fall (May) in three consecutive seasons for different blueberry cultivars (Corona, Legacy, and Liberty) and $\mathrm{N}$ fertilization treatments; A) 2011-2012, blueberry cultivars; B) 2011-2012, N fertilization treatments; C) 2012-2013, blueberry cultivars; D) 2012-2013, N fertilization treatments; E) 2013-2014, blueberry cultivars; F) 20132014, $N$ fertilization treatments.
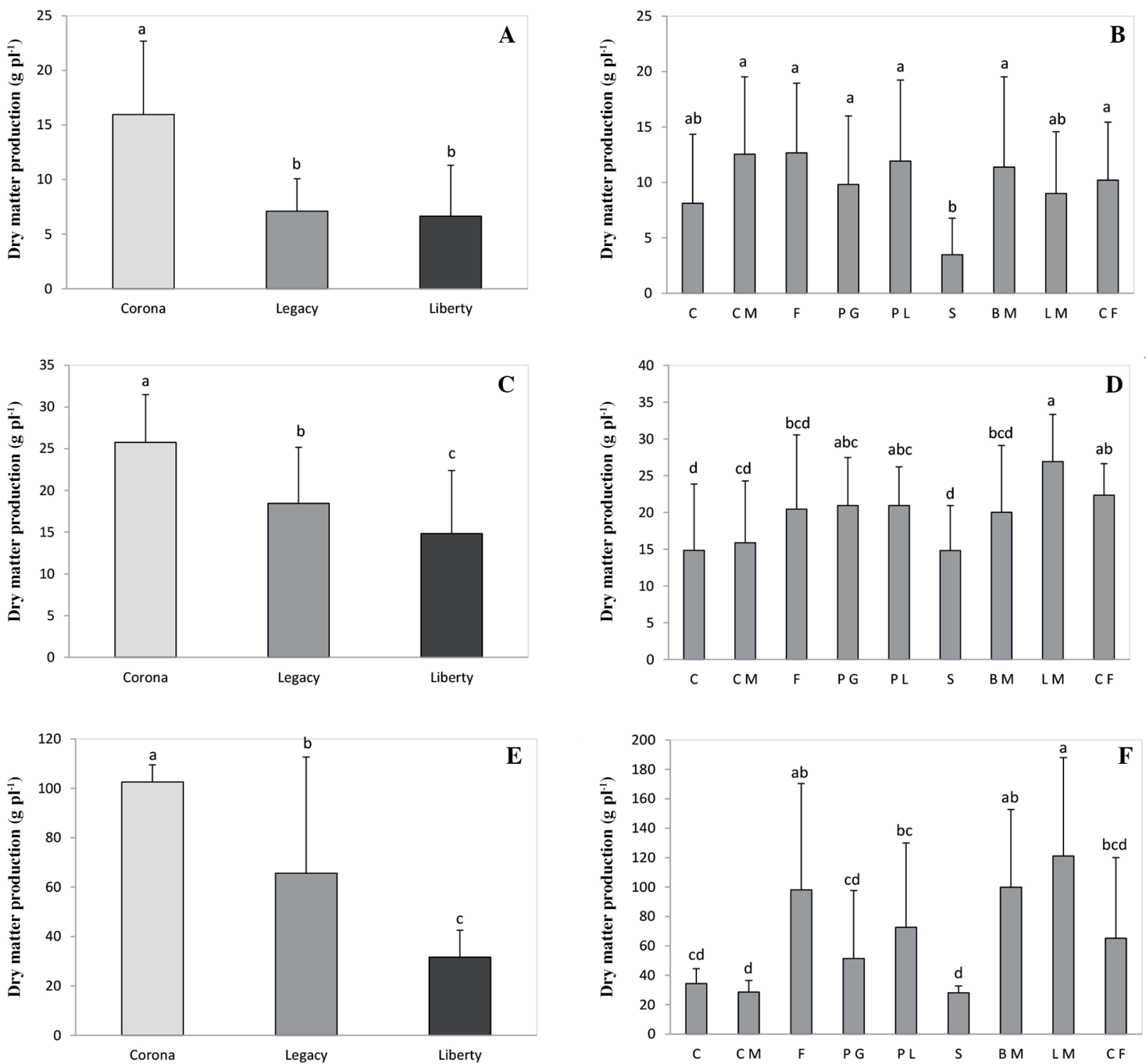

Treatments: Compost (CM), Purely Grow (PG), Purely Lysine (PL), Fertil (F), blood meal (BM), lupine meal (LM), control treatment with no fertilization (C), and two conventional treatments with urea $(\mathrm{CF})$ and sodium nitrate $(\mathrm{S})$.

that ranged from 104.25 to $341.54 \mathrm{~g} \mathrm{plant}^{-1}$; the highest yield was achieved using $\mathrm{F}$ and $\mathrm{LM}$, which was only higher than the values obtained for $\mathrm{C}, \mathrm{CM}, \mathrm{PG}, \mathrm{S}$, and $\mathrm{BM}(\mathrm{p}<0.05)$ (Figure 4b). Mean fruit weight in the 2013-2014 season ranged from 1.56 to $2.63 \mathrm{~g}$ (Figures $4 \mathrm{c}$ and $4 \mathrm{~d}$ ); the highest weight was obtained in 'Corona' followed by 'Legacy' and 'Liberty'; there were no differences between them ( $p$ > $0.05)$. No differences were found for this parameter when comparing $\mathrm{N}$ sources, $(\mathrm{p}>0.05)$.

\section{DISCUSSION}

The present study focused on the effects of $\mathrm{N}$ supply through different organic sources as related to conventional fertilizers, as well as in the response of three blueberry cultivars. Effects of other nutrient supply with the different nutritional sources were not discussed; there are several reports indicating that the main nutrient affecting the parameters analyzed in the present study is N (Tamada, 2004; Bryla and Machado, 2011; Bañados et al., 2012; Retamales and Hancock, 2012).

Vegetative growth of blueberry plants, expressed as the sum of the lengths of basal and lateral shoots in $\mathrm{cm}^{\text {plant }}{ }^{-1}$, was quantitatively higher in the 2013-2014 season compared to the 2012-2013 season for the three cultivars. The accumulation of vegetative growth (sum of lengths of basal and lateral shoots) in the 2012-2013 season in 'Legacy' and 'Liberty' was 70.0\% and $88.0 \%$, respectively, compared to 'Corona' (Table 2). The accumulation of vegetative growth in 'Legacy' and 'Liberty' 
Figure 2. Leaf $\mathbf{N}$ concentration in three consecutive seasons for different evaluated blueberry cultivars (Corona, Legacy, and Liberty) and $\mathrm{N}$ fertilization treatment used; A) 2011-2012, blueberry cultivars; B) 2011-2012, N fertilization treatments; C) 20122013, blueberry cultivars; D) 2012-2013, N fertilization treatments; E) 2013-2014, blueberry cultivars; F) 2013-2014, N fertilization treatments.
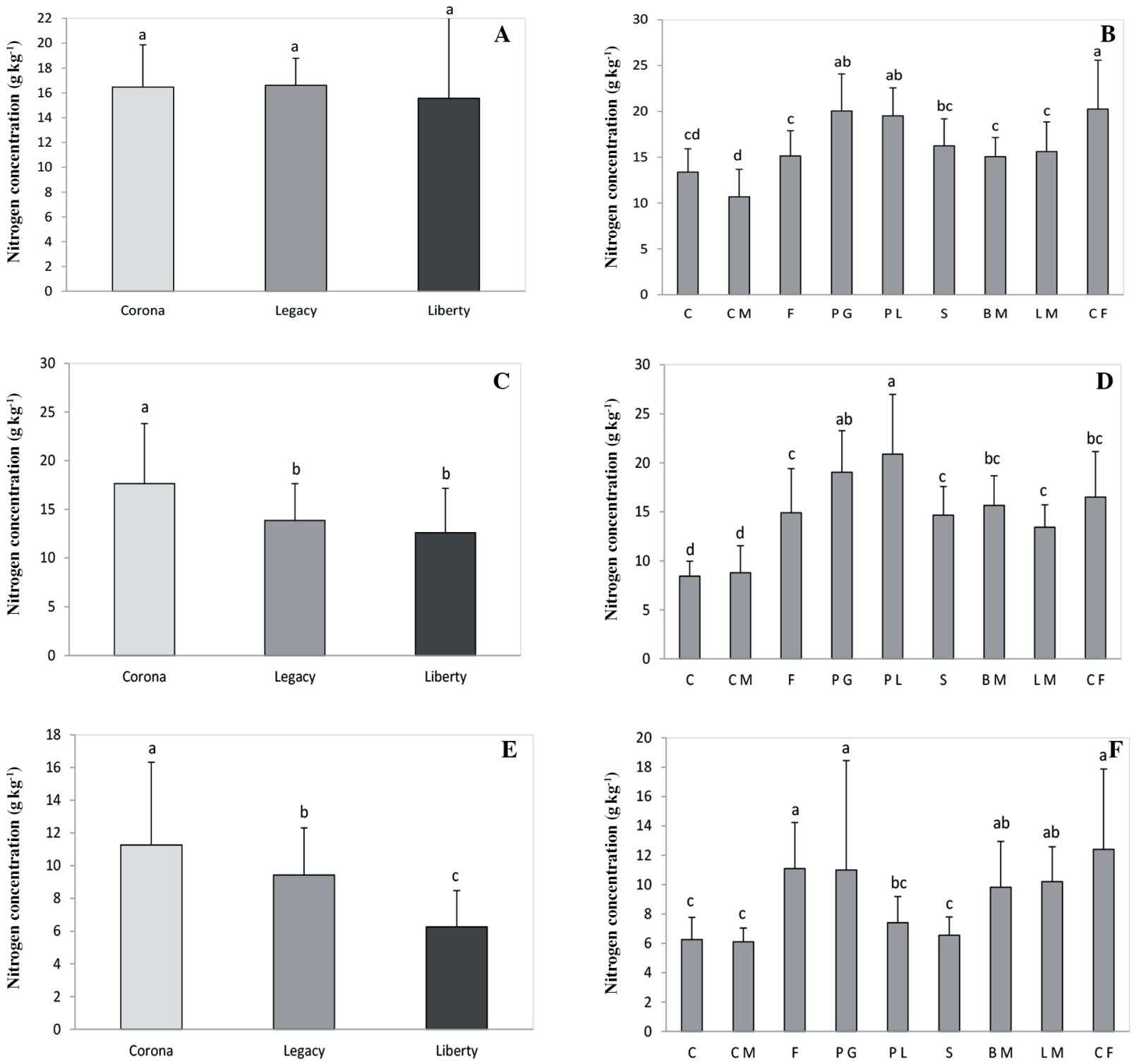

Treatments: Compost (CM), Purely Grow (PG), Purely Lysine (PL), Fertil (F), blood meal (BM), lupine meal (LM), control treatment with no fertilization (C), and two conventional treatments with urea $(\mathrm{CF})$ and sodium nitrate $(\mathrm{S})$.

was $84.0 \%$ and $83.0 \%$, respectively, compared to 'Corona' for the 2013-2014 season (Table 2). At the same time, the increase in vegetative growth for each cultivar between the 2012-2013 and 2013-2014 seasons was $64.0 \%, 97.0 \%$, and $55.0 \%$ for 'Corona', 'Legacy', and 'Liberty', respectively. There were quantitative differences between cultivars for the sum of the number of lateral and basal shoots (Table 2). The sum of the number of shoots in the 2012-2013 season for 'Legacy' and 'Liberty' was $42.5 \%$ and $59.1 \%$, respectively, compared to 'Corona', and values were $65.2 \%$ and $69.7 \%$ for 'Legacy' and 'Liberty', respectively, compared to 'Corona' for the 2013-2014 season. At the same time, the increase in the sum of the number of lateral and basal shoots in each cultivar between the 20122013 and 2013-2014 seasons was 63.5\%, 150.6\% and $92.9 \%$ for 'Corona', 'Legacy', and 'Liberty', respectively. These differences are explained by the vigor conditions described for the three evaluated cultivars (San Martín, 2013). A higher difference between cultivars was found for the sum of the number of lateral and basal shoots, which could be associated with a compensation effect between both the number and length of shoots: moreover, the difference between cultivars, as a percentage, was lower for the sum of the lengths of the basal and lateral shoots. 'Corona' is one of the new cultivars on the market; it is an early-season cultivar with high productivity. On the other hand, 'Liberty' is a mid-to-late season cultivar which depends on the agro-climatic zone where the plants are grown, and it has relatively vigorous growth. 'Legacy' is a mid-season cultivar with vertical and vigorous growth. 
Figure 3. Nitrogen extraction in three consecutive seasons for different blueberry cultivars (Corona, Legacy, and Liberty) and $\mathbf{N}$ fertilization treatments; A) 2011-2012, blueberry cultivars; B) 2011-2012, N fertilization treatments; C) 2012-2013, blueberry cultivars; D) 2012-2013, N fertilization treatments; E) 2013-2014, blueberry cultivars; F) 2013-2014, $N$ fertilization treatments.
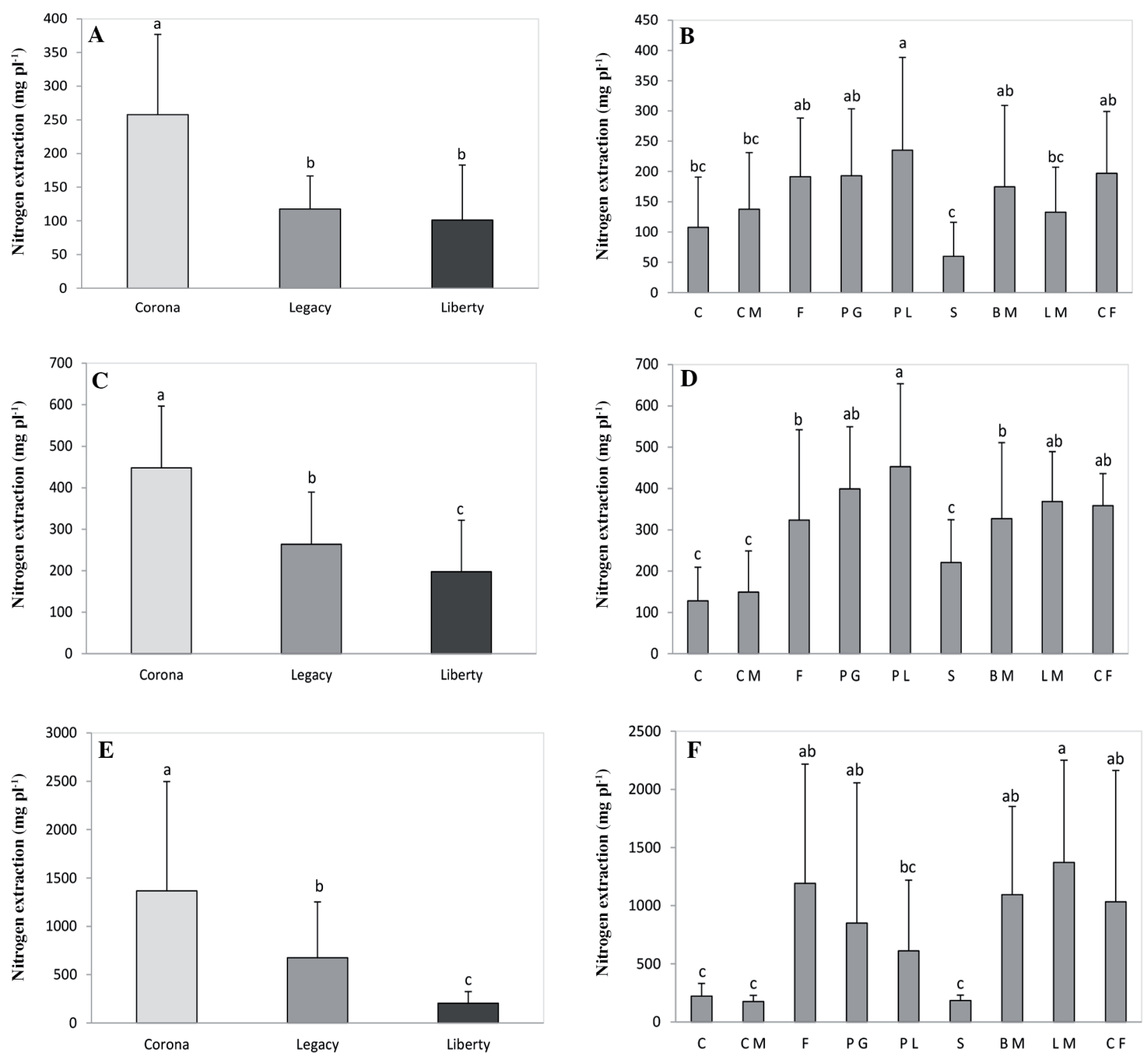

Treatments: Compost (CM), Purely Grow (PG), Purely Lysine (PL), Fertil (F), blood meal (BM), lupine meal (LM), control treatment with no fertilization (C), and two conventional treatments with urea $(\mathrm{CF})$ and sodium nitrate $(\mathrm{S})$.

'Liberty' also has a later ripening season compared to the other cultivars under study. Therefore, it has lower $\mathrm{N}$ uptake in the postharvest period (Larco et al., 2013). It is important to note that optimal timing for applying $\mathrm{N}$ fertilizer is determined by the uptake pattern of the fruit in each phenological stage (Bañados et al., 2012), and most of the uptake occurs between sprouting and veraison (Hanson, 2006; Bañados, 2006). In the case of blueberries, each cultivar has an individual $\mathrm{N}$ consumption pattern, which could explain interactions between cultivars and $\mathrm{N}$ sources obtained in each season, as well as differences in their response to both cultivar and $\mathrm{N}$ source between seasons. The different effects of $\mathrm{N}$ sources between seasons (Table 1, Figures 1b, 1d, and 1f) could be associated with the behavior of both the vegetative and reproductive development of each cultivar, and vegetative development depends on $\mathrm{N}$ availability (Bryla and Machado, 2011). The sandy loam used could generate loss by lixiviation of fast release $\mathrm{N}$ sources, so the sources of medium release, such as LM, could generate a higher adjustment between $\mathrm{N}$ uptake and supply.

The $\mathrm{N}$ source with the best result for vegetative growth was LM, whose effect was previously explained. In contrast, the control without $\mathrm{N}$ had the lowest values, and the lack of $\mathrm{N}$ limited the synthesis of proteins, nucleic acids, phospholipids, and a number of secondary metabolites (Miller and Cramer, 2004), which affected vegetative development and the next reproductive stage. The application of $\mathrm{N}$ sources from different origins and composition promotes the growth of beneficial 
Figure 4. Fruit production and fruit weight for the December 2013-February 2014 harvest; A) Production per plant for the different blueberry cultivars (Corona, Legacy, and Liberty); B) production per plant for $\mathrm{N}$ fertilization treatments; $\mathrm{C}$ ) fruit weight for different cultivars; D) fruit weight for $\mathbf{N}$ fertilization treatments.
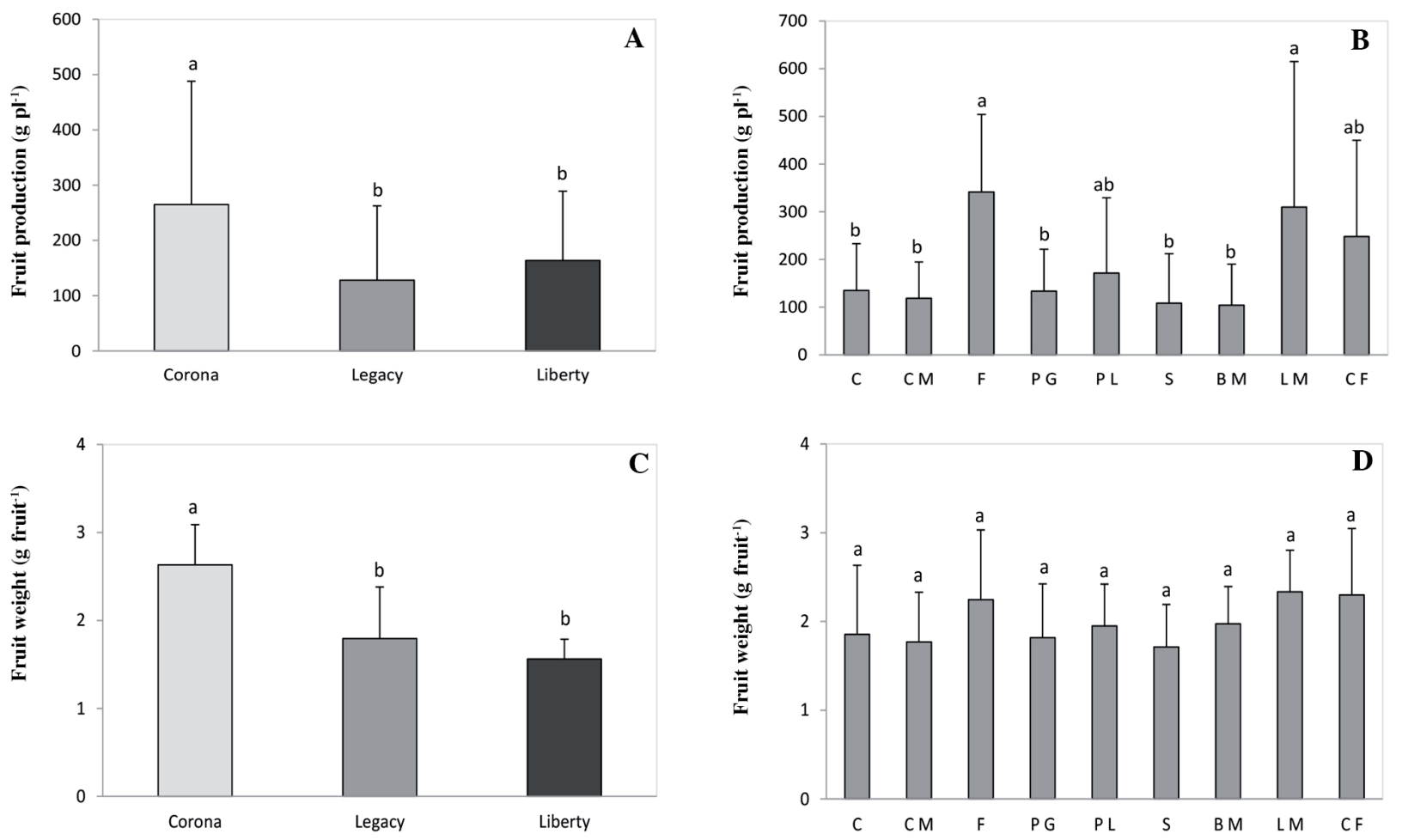

Treatments: Compost (CM), Purely Grow (PG), Purely Lysine (PL), Fertil (F), blood meal (BM), lupine meal (LM), control treatment with no fertilization (C), and two conventional treatments with urea $(\mathrm{CF})$ and sodium nitrate $(\mathrm{S})$.

soil microorganisms associated with the root system of blueberries, higher uptake capacity, and essential nutrient concentration (Ruan et al., 2010). Treatment $\mathrm{S}$ ( $\mathrm{N}$ as sodium nitrate) had a negative effect on the blueberries, which is explained by fast $\mathrm{Na}$ release in the sandy loam soil that produces toxicity in blueberries (Bryla and Machado, 2011; Bañados et al., 2012). Therefore, reduced vegetative growth and lower DM production were expected, as observed in the three evaluated cultivars; values were below or similar to the control treatment. Based on $\mathrm{N}$ contribution, fast release treatments of N such as PG and FC could have had greater shoot growth; however, these treatments could have had higher N loss through leaching (Hirzel, 2014), which is an effect not determined in the present study.

Leaf DM production in the three cultivars was higher in 'Corona' during the three seasons and proportionally higher in the first season (Figure 1A); it is associated with the initial vigor described for this cultivar (San Martín, 2013). The higher leaf DM production in 'Corona' in this experiment is explained by the increased accumulation of reserves in an aging plant, which results in higher leaf mass and roots, and therefore has greater primary and secondary productivity (Budeguer et al., 2011). In the last two evaluated seasons, the highest levels of leaf DM were obtained with treatments based on meals (BM and LM) in the three cultivars under study (Figure 1), as well as the $\mathrm{F}$ treatment. These fertilizers decompose very easily and are associated with its $\mathrm{C}: \mathrm{N}$ ratio, low molecular weight compounds, and high presence of amino acids with a low C:N ratio (Fuller, 2004). In fact, some authors have reported that there may be $50 \%$ decomposition $30 \mathrm{~d}$ after the application, so that $\mathrm{N}$ is readily available to plants and can be easily released (Müller and von Fragstein, 2006; Hirzel, 2014).

The leaf $\mathrm{N}$ concentration interactions for the 2013-2014 season (Figure 2) can be explained by the differences in leaf mass and $\mathrm{N}$ uptake period of each cultivar (Bañados et al., 2012), which in turn are associated with the dynamic $\mathrm{N}$ release of each source used (Hirzel, 2014). 'Corona' was the cultivar that accumulated the highest leaf $\mathrm{N}$ content followed by 'Legacy' (Figure 2). Both 'Corona' and 'Legacy' are considered as vigorous cultivars with early- and mid-season fruiting (longer postharvest period to accumulate reserves that promote vegetative growth in the following season). These results are consistent with those reported by Miller et al. (2006), who compared the uptake and accumulation of macronutrients in 2-yr-old blueberry plants under organic and conventional farming. This study showed that organically grown plants had lower $\mathrm{N}$ and $\mathrm{P}$ leaf concentration than plants treated with conventional fertilizers. Leaf symptoms were also evidenced in this study and the researchers determined that supplying effective nutrient rates with organic fertilizers is more difficult. In addition, Bañados 
et al. (2012) has indicated that when these nutrients are more available, uptake is quicker and improves tissue concentration the same as conventional fertilizers do. Leaf $\mathrm{N}$ uptake prior to leaf fall (Figures 3A, C, and F) is an indicator of $\mathrm{N}$ recovery capacity, which exhibited the same behavior as leaf DM production (Figures 1A, C, and F); this effect was previously discussed. The effect of leaf $\mathrm{N}$ concentration prior to leaf fall is quantitatively lower for $\mathrm{N}$ extraction (Figures 2A, C, and F). Accumulated leaf $\mathrm{N}$ uptake during the three evaluated seasons with each fertilization treatment was 1.87 (LM), 1.71 (F), 1.60 (BM), 1.59 (CF), 1.44 (PG), $1.30(\mathrm{PL}), 0.46(\mathrm{C}), 0.46(\mathrm{CM})$, and $0.46(\mathrm{~S}) \mathrm{g} \mathrm{pl}^{-1}$ with an accumulated rate of $56 \mathrm{~g} \mathrm{~N}$ plant $^{-1}$ in the three seasons of the experiment. These uptake values were much lower than those reported by Bañados et al. (2012) for the leaves of the cultivar 'Bluecrop' collected prior to leaf fall (October in the Northern Hemisphere) for a 2-yr experiment in Oregon in a fine loamy soil fertilized with ammonium sulfate. This lower $\mathrm{N}$ recovery could be associated with the soil used in the present experiment because of the higher risk of losses by lixiviation and lower $\mathrm{N}$ availability of the fertilizers used. The time of leaf sampling in the present experiment was May (November in the Northern Hemisphere). This difference of one month between both sampling dates could also explain the lower $\mathrm{N}$ recovery associated with higher $\mathrm{N}$ translocation to other plant structures prior to leaf fall.

For $\mathrm{N}$ extraction by different blueberry cultivars during the growing season, authors such as Bañados (2006), Gale et al. (2006), and Hanson (2006) have indicated that $\mathrm{N}$ fertilizers should be applied at different rates depending on the cultivar. This coincides with the findings of the present study because 'Liberty' had lower levels of leaf N extraction compared to 'Corona' and 'Legacy'.

Measurements of mean fruit weight and yield per plant were affected by the interaction between cultivars and evaluated $\mathrm{N}$ sources. This interaction is associated with differences in the vigor of each cultivar. Other studies have reported that 'Legacy' showed lower photosynthesis than 'Bluegold' in the absence of N (Yañez-Mansilla et al., 2014). In blackberries, the cultivar plays a key role in the $\mathrm{N}$ source and $\mathrm{N}$ application rate (Fernández-Salvador et al., 2015). The effect of seasonality on $\mathrm{N}$ uptake, which is related to fruit earliness, is also associated with the speed of $\mathrm{N}$ release. 'Corona' had a higher mean fruit weight of 2.64 $\mathrm{g}$ fruit $^{-1}$, which was within the range of values described for this cultivar (Lobos et al., 2011). 'Legacy' and 'Liberty' had mean weights of 1.78 and $1.56 \mathrm{~g}_{\text {fruit }^{-1}}$, respectively. These values were lower than those obtained for 'Corona', but they were also within the range of values for this cultivar (Serri and Hepp, 2006; Retamales et al., 2014). The N sources that were used did not generate any significant differences on these parameters. However, fruit weight was higher when using LM, CF, and F in variable $g$ fruit $^{-1}$ (Figure 4D). Treatments that had the lowest mean fruit weight values of were S, CM, and C (Figure 4D). This effect can be attributed to the reduced availability of $\mathrm{N}$ in treatments $\mathrm{C}$ and $\mathrm{CM}$ and also to the negative effect of using $\mathrm{S}$ in this sandy soil; $\mathrm{N}$ availability, especially at the beginning of vegetative growth, is closely related to the productivity of blueberry plants (Stadler et al., 2006). Fruit yield per plant is also associated with the pruning operations conducted in the preceding winter season, which consisted in leaving flower buds in accordance with the vegetative development of the plant. Thus, weaker plants or those with fewer shoots were pruned more severely than vigorous plants in order to stimulate growth, yield, and fruit quality in the long term (Williamson et al., 2004).

\section{CONCLUSIONS}

Vegetative growth of evaluated blueberry plants has an effect on the cultivar, and it is also affected by the $\mathrm{N}$ source used. 'Corona' had higher vegetative growth than 'Legacy', which in turn was higher than 'Liberty'. Quickrelease $\mathrm{N}$ sources, such as urea, Purely Grow, and Purely Lysine, generated higher vegetative growth in 'Legacy', while the use of lupine meal generated a higher growth rate in 'Corona' and 'Liberty'.

Leaf $\mathrm{N}$ accumulation prior to leaf fall showed differences between cultivars, seasons, or plant development stage and had effects depending on the N source used. 'Corona' had the highest accumulation, while the $\mathrm{N}$ sources that achieved the highest accumulation were urea and Purely Lysine in the first two seasons and urea, Fertil, and Purely Grow in the last season. As the plants aged, lower leaf $\mathrm{N}$ accumulation was observed.

Fruit production varied depending on the cultivar and $\mathrm{N}$ source used. The highest yield was observed in 'Corona' followed by 'Legacy' and 'Liberty'. The N sources that achieved the highest fruit yield were lupine meal and Fertil. Fruit weight only depended on the cultivar and the highest values were obtained in 'Corona' followed by 'Legacy' and 'Liberty', and they were not affected by the $\mathrm{N}$ source used. Leaf chlorophyll content showed differences between cultivars and $\mathrm{N}$ sources. 'Corona' had the highest values followed by 'Legacy' while 'Liberty' reached lower values. The $\mathrm{N}$ sources that achieved the highest leaf chlorophyll content were urea, lupine meal, blood meal, and Purely Grow.

Finally, under the conditions of this experiment, lupine meal obtained the highest values for most of the evaluated parameters. As for the cultivar, 'Corona' had the highest values for these parameters. These results suggest that future experiments about organic fertilization in blueberry must include combinations of different $\mathrm{N}$ sources and consider fast, medium, and slow $\mathrm{N}$ supply rates.

\section{ACKNOWLEDGEMENTS}

The authors would like to thank the Foundation for Agricultural Innovation (FIA) through project PYT-20110064 and the Chilean company 'Hortifrut Chile S.A' for their financial support. 


\section{REFERENCES}

Bañados, M. 2006. Blueberry production in South América. Acta Horticulturae 715:165-172.

Bañados, M.P., B.C. Strick, D.R. Bryla, and T.L. Righetti. 2012. Response of high bush blueberry to nitrogen fertilizer during field establishment. I. Accumulation and allocation of fertilizer nitrogen and biomass. HortScience 47(5):648-655.

Brazelton, D., and B.C. Strik. 2007. Perspective on the U.S. and global blueberry industry. Journal of the American Pomological Society 61:144-146.

Bryla, D., J. Gartung, and B.C. Strik. 2006. Evaluation of irrigation methods for highbush blueberry. I. Growth and water requirements of young plants. HortScience 46(1):95-101.

Bryla, D.R., and R.M.A. Machado. 2011. Comparative effects of nitrogen fertigation and granular fertilizer application on growth and availability of soil nitrogen during establishment of highbush blueberry. Frontiers in Plant Science 2:1-8.

Bryla, D.R., and B.E. Strik. 2007. Effects of cultivar and plant spacing on the seasonal water requirements of highbush blueberry. HortScience 132:270-277.

Budeguer, R., J. Rodríguez, C. Brandán de Weht, y D. Diéguez. 2011. Partición de fotosintatos en un cultivar de arándano (Vaccinium corymbosum L.) Biología en Agronomía 1(1):74-81.

Burkhard, N., D. Lynch, D. Percival, and M. Sharifi. 2009. Organic mulch impact on vegetation dynamics and productivity of highbush blueberry under organic production. HortScience 44:688-696.

CIREN. 1999. Descripciones de suelos materiales y símbolos: Estudio Agrológico VIII Región. Publicación CIREN N ${ }^{\circ} 121$. 583 p. Centro de Información de Recursos Naturales (CIREN), Santiago, Chile.

Crisóstomo, M., O. Hernández, J. López, C. Manjarrez-Domínguez, y A. Pinedo-Alvárez. 2014. Relaciones amonio/nitrato en soluciones nutritivas ácidas y alcalinas para arándano. Revista Mexicana de Ciencias Agrícolas 5(3):525-532.

Fernández-Salvador, J., B.C. Strik, and D.R. Bryla. 2015. Liquid corn and fish fertilizers are good options for fertigation in blackberry cultivars grown in an organic production system. HortScience 50(2):225-233.

Fuller, M.F. 2004. The encyclopedia of farm animal production. 606 p. CAB International, Wallingford, UK.

Gale, E.S., D.M. Sullivan, D. Hemphill, C.G. Cogger, A.I. Bary, and E.A. Myhre. 2006. Estimating plant-available nitrogen release from manures, composts, and specialty products. Journal of Environmental Quality 35:2321-2332.

Hanson, E.J. 2006. Nitrogen fertilization of highbush blueberry. Acta Horticulturae 715:347-351.

Hirzel, J. 2014. Diagnóstico nutricional y principios de fertilización en frutales y vides. Segunda edición aumentada y corregida. Colección Libros INIA. $\mathrm{N}^{\circ}$ 31. Instituto de Investigaciones Agropecuarias INIA, Chillán, Chile.

Hirzel, J., F. Cerda, P. Millas, and A. France. 2012. Compost tea effects on production and extraction of nitrogen in ryegrass cultivated on soil amended with commercial compost. Compost Science \& Utilization 20(2):97-104.

Holzapfel, E.A., R.F. Hepp, and M.A. Mariño. 2004. Effect of irrigation on fruit production in blueberry. Agricultural Water Management 67:173-184.

Kozinski, M. 2006. Influence of mulching and nitrogen fertilization rate on growth and yield of highbush blueberry. Acta Horticulturae 715:231-235.
Krewer, G., M. Tertuliano, P. Andersen, O. Liburd, G. Fonsah, H. Serri, et al. 2009. Effect of mulches on the establishment of organically grown blueberries in Georgia. Acta Horticulturae 810:483-488.

Larco, H.O. 2010. Effect of planting method, weed management, and fertilizer on plant growth and yield of newly established organic highbush blueberries. MSc thesis. Oregon State University, Corvallis, Oregon, USA.

Larco, H., B.C. Strik, D.R. Bryla, and D.M. Sullivan. 2013. Mulch and fertilizer management practices for organic production of highbush blueberry. I. Plant growth and allocation of biomass during establishment. HortScience 48:1250-1261.

Lester, G.E. 2006. Organic versus conventionally grown produce: quality differences, and guidelines for comparison studies. HortScience 41(2):296-300.

Lobos, T., H. Pinilla, y W. Lobos. 2011. Efecto de aplicaciones de calcio en la calidad de la fruta de arándano alto (Vaccinium corymbosum L.) cv. Elliot. IDESIA 29(3):59-64.

Miller, A.J., and M.D. Cramer. 2004. Root nitrogen acquisition and assimilation. Plant and Soil 274:1-36.

Miller, S.A., N. Patel,A. Muller, D.M.Edwards, and S.T. Solomona. 2006. A comparison of organic and conventional nutrient management protocols for young blueberry nursery stock. Acta Horticulturae 715:427-432.

Müller, T., and P. von Fragstein. 2006. Organic fertilizers derived from plant materials Part I: Turnover in soil at low and moderate temperatures. Journal of Plant Nutrition and Soil Science 169:255-264.

Retamales, J.B., R. Godoy, C. Moggia, G.A. Lobos, and S. Romero. 2014. CPPU Sprays alter blueberry (Vaccicum corymbosum L. 'Duke') fruit quality at harvest and its behavior in postharvest. Acta Horticulturae 1017:189-193.

Retamales, J.B., and J.F. Hancock. 2012. Blueberries. p. 4-12. CABI, Cambridge, Massachusetts, USA.

Ruan, J., R. Hardter, and J. Gerendás. 2010. Impact of nitrogen supply on carbon/nitrogen allocation: a case study on amino acids and catechins in green tea Camellia sinensis (L.) O. Kuntze plants. Plant Biology 12:724-734.

Sadzawka, A., R. Grez, M.L. Mora, N. Saavedra, M.A. Carrasco, H. Flores, et al. 2004. Métodos de análisis de tejidos vegetales. p. 113. Comisión de Normalización y Acreditación Sociedad Chilena de la Ciencia del Suelo. Editorial Salesianos Impresores, Santiago, Chile.

San Martín, L. 2013. Situación varietal en arándano. p. 15-21. In Undurraga, P., y S. Vargas (eds.) Manual de arándano. Boletín INIA N ${ }^{\circ}$ 263. Instituto de Investigaciones Agropecuarias INIA, Chillán, Chile.

Serri, H., and R. Hepp. 2006. Effect of the growth regulator CPPU on fruit quality and fruit ripening of highbush blueberries. Acta Horticulturae 715:279-282.

Stadler, C., S. von Tucher, U. Schmidhalter, R. Gutser, and H. Heuwinkel. 2006. Nitrogen release from plant-derived and industrially processed organic fertilizers used in organic horticulture. Journal of Plant Nutrition and Soil Science 169:549-556.

Strik, B. 2014. Organic blueberry production systems - Advances in research and industry. Acta Horticulturae 1017:257-267.

Strik, B., and G. Buller. 2005. The impact of early cropping on subsequent growth and yield of highbush blueberry in the establishment years at two planting densities is cultivar dependent. HortScience 40:1998-2001.

Tamada, T. 2004. Effects of nitrogen sources on growth and leaf nutrient concentrations of 'Tifblue' rabbiteye blueberry under water culture. Small Fruits Review 3(1-2):149-158. 
Vargas, O.L., and D.R. Bryla. 2015. Growth and fruit production of Highbush blueberry fertilized with ammonium sulfate and urea applied by fertigation or as granular fertilizer. HortScience 50(3):479-485.

Wang, S.Y., C. Chen, W. Sciarappa, C.Y. Wang, and M.J. Camp. 2008. Fruit quality antioxidant capacity and flavonoid content of organically and conventionally grown blueberries. Journal of Agricultural and Food Chemistry 56:5788-5794.
Williamson, J.G., F.S. Davies, and P.M. Lyrene. 2004. Pruning blueberry plant in Florida. Institute of Food and Agricultural Sciences, Gainesville, Florida, USA.

Yañez-Mansilla, E., P. Cartes, M. Reyes-Diaz, A. RiberaFonseca, and M. Alberdi. 2014. Photosynthetic and antioxidant performance are differentially affected by short-term nitrogen supply in highbush blueberry cultivars. Ciencia e Investigación Agraria 41(1):61-70. 